\title{
MISALIGNMENT OF INTEREST: AN ACTOR- NETWORK ANALYSIS OF A GOVERNMENT BUDGETING PRACTICE
}

\author{
CHANDRASIRI ABEYSINGHE1,*
}

Received: 3 May 2020 / Revised: 6 September 2020, 1 October 2020 / Accepted: 9 October 2020

Published online: 29 January 2021

(C) 2021 Faculty of Business and Accountancy, University of Malaya. All rights reserved.

\section{A B S T R A C T}

Research aim: This paper aims at finding an explanation as to why a government budget operates as a ritual, as has been observed in the Sri Lankan Government budgeting practice and many Less Developed Country (LDC) accounting studies.

Design/ Methodology/ Approach: Designed to be a historical study, this study illustrates the government budgeting practice referring to the Sri Lanka Railway Department (SLRD), benefitting from Actor-Network Theory (ANT) using data from archival sources, content analysis of documents, published materials and interviews.

Research finding: This research finds that accounting and control practices dysfunction when they do not support the aligned interests of the underlying actor-network.

Theoretical contribution/ Originality: This paper focuses on the 'aligned interest' of an actornetwork, tracking changes of human and non-human actors of a ruling network over three ruling regimes within 1815 to 2019, illuminating the use of ANT in analysing how accounting practices develop over time.

Practitioner/ Policy implication: This research reveals to practitioners in the LDC context, a reason for budgeting to operate as a ritual, helping them to formulate necessary action. To the policymaker, this research reveals that for successful performance, the overall policy framework must address the underlying dominant interest.

Research limitation: This research focuses on a single aligned interest in an actor-network. However, some public sector institutions operate with multiple interests. Further studies are needed to understand how accounting and control practices in such a context.

Keywords: Government budgeting, Actor-Network Theory, Colonial legacies in accounting, LDC accounting and controls, Political interest in public sector accounting

Type of article: Research paper

JEL Classification: H61, H72, H83, M48

\section{Introduction}

Most Less Developed Country (LDC) accounting and control studies focus on budgeting and reveal its ritualistic practice. For instance, Adhikari et al. (2013), Hopper et al. (2009), Hoque and Hopper (1994), Tsamenyi et al. (2006), Uddin and Hopper (2001), Wickramasinghe and Hopper (2005), Wijewardena and Yapa (1998) revealed how accounting and control systems, including

\footnotetext{
${ }^{1}$ Faculty of Management \& Finance, University of Colombo, 166, 19A Bauddhaloka Mawatha, Colombo 00700, Sri Lanka. *e-mail: c_abey@dac.cmb.ac.lk / abeycolombo@gmail.com
} 
budgeting, operate without serving their original intentions. This paper identifies accounting practice as a ritualist practice because, in a broader sense, rituals are routinised and habitual actions.

Sri Lanka's government budgeting practice reproduces the characteristics of a ritual. According to Bell (1992), a ritual is a "thoughtless actionroutinised, habitual, obsessive, or mimetic - and therefore the purely formal, secondary, and mere physical expression of logically prior ideas" (p. 19). Accordingly, rituals are formal but thoughtless and habitual actions. The government budgeting practice demonstrates this practice, whereby every government institution spends according to the budget, but it has no relevance to government operations. Further, rituals are rule-governed, routine, formalised, ordered, repetitious and stylised activities that are performed in social spaces drawing the attention of participants to an object that they feel is of particular importance (Goodsell, 1989; Lukes, 1975; McComas et al., 2010; Smith \& Stewart, 2011; Uche \& Atkins, 2015). Sri Lanka's government budget is critical, and an event for which the general public anticipates to learn of the government's policy framework concerning expenditure. Studying why an important accounting control process becomes a ritual could be a novel contribution to the body of accounting knowledge.

Most LDC studies identify colonial legacies behind the development of their accounting practices due to the colonial history of most LDCs (Hopper et al., 2009). Sri Lanka has been unable to significantly change the accounting and control systems stemming from colonial rule (Hopper et al., 2009; Wijewardena \& Yapa, 1998). Colonialism has given rise to an adverse politico-economic condition in postcolonial LDCs (Davie \& McLean, 2017; Davie, 2000; Hemming \& Mansoor, 1988; Hopper et al., 2009; Uddin \& Hopper 2001). Due to poverty created by colonial rule, state politics had to play a significant role in postcolonial states compared to advanced industrial countries (Hopper et al., 2009) resulting in ruling politicians' attempt to interfere in control systems to placate their political supporters (Uddin \& Hopper, 2001; Uddin \& Tsamenyi, 2005; Wickramasinghe \& Hopper, 2005). In such a situation, as Pfeffer (1981) claimed, in LDCs, budgeting becomes an objective mechanism of legitimising subjective political decisions on resource allocation.

Colonial control systems focused on economic development as the primary object (Nkrumah, 1973). Those accounting and control systems are unable to serve economic development needs in the postcolonial state because they suffer from insufficient recognition of indigenous circumstances, needs and participation, causing implementation problems (Hopper et al., 2017). These findings motivate exploring how colonial legacies are involved in accounting control systems. This paper sheds light on the question of how colonial legacies render the government budgeting system of Sri Lanka a ritual. 
The government comprises a set of institutions such as Presidential Secretariat, Prime Minister's office, Ministries and Departments. The budgeting system is the same for all government institutions. Hence, studying the budgeting practice of a selected state institution enables knowing the government budgeting practice of Sri Lanka. Accordingly, this paper uses the budgeting practice of Sri Lanka Railways Department (SLRD), which is a state department established in 1864 to serve the transportation needs of the colonial rulers of Ceylon (the then Sri Lanka). The Review of Administration Reports of SLRD shows the history of change of its financial performance. The SLRD had profitable operations during the colonial rule (up to 1948). However, from 1949 to 1976, it had operated with a steady loss. The remarkable deterioration in financial performance occurred from 1977 up to today incurring increasingly substantial financial losses every year. For the year 2017, it was Rs. 7,605 Million (USD 47 Million). Altogether nearly 18,000 people are employed, and this department is sensitive to the ruling political party to remain in power due to subsidised railway transportation provided to people. Historically, the trade union operates extensively within this department.

The National Budget Department of the Ministry of Finance coordinates and controls the government budgeting process, which controls spending by government institutions. Each government institution uses the approved budget as a guide in spending, and none can exceed the limit without approval of the Parliament. The form of the budget is the same for each institution.

As a continuation of the colonial practice, today, the Treasury Department of the Ministry of Finance controls the finance function in Sri Lanka. The National Budget Department comes under the Treasury Department. Hence, this paper uses the term 'Treasury Control' to denote government control over the use of public funds.

The researcher's investigations into the current SLRD budgeting practice reveal two contradictions. One is the contradiction between the Treasury's economic rationale to maintain the economy in operations of the SLRD, and the Transport Minister's political rationale to carry operations of SLRD to the satisfaction of SLRD employees and the general public. However, the political rationale seems to dominate over the economic rationale, and accordingly, the SLRD ignores such economic concerns of the Treasury. The other issue is the contradiction between the Treasury's economic rationale and its format of the budget. The Treasury issues the budget format, stipulating expenditure limits referring to generic categories of expenditure items such as personal emoluments, travelling, and utility services. It does not provide information as to the expectations of operational performance such as the number of trains going to operate, the number of engine drivers to operate, the number of support service operatives required and the cost of fuel. In consequence, this 
format detaches the SLRD budget from its operations with no support to the economic rationale of the Treasury.

Despite concerns of the Treasury and the SLRD, the government budgeting system continues as merely a statutory requirement detached from operational control. The objective of the current study is to understand how this budgeting practice has been formed. The intention of the study suggests two research questions: (i) how the postcolonial government budgeting practice manifest the colonial legacies and (ii) why such a practice becomes a ritual. From the ANT perspective, this study identifies establishing the colonial rule in Ceylon as a formation of a ruling network.

The next section of the paper locates this paper within the existing body of knowledge, followed by the explanation of the use of ANT, especially in accounting studies. Afterwards, the paper explains its methodological choice. The next section presents data illuminating how budgeting and other control systems arrived as non-human actors into the colonial ruling network, and how they continued to the postcolonial state. Finally, from the ANT perspective, the paper concludes as to how the current government budgeting system manifests colonial legacies, and why it operates as a ritual.

\section{Literature Review}

Most LDCs have been colonies of Western powers in their histories (Alama et al., 2004; Hopper et al., 2009;) and share two common interrelated characteristics: (i) adverse socio-political and economic conditions, and (ii) colonisation in their histories. These countries are prone to economic, social and physical crises, political instability and quite often regime changes (Hopper et al., 2009). Helden and Uddin (2016) recognise that these countries are passing the market-led economic development stage but influenced by externally imposed unsuccessful economic reforms to operate with the characteristics of old state-led development practices. In this context, operational decisions are based on political patronage, seeking to bolster political support rather than legal-rational, bureaucratic or economic criteria (Hopper et al., 2009).

The managerial systems developed in the colonies were conducive to the cultural, political and economic goals of colonialism (Frenkel \& Shenhav, 2006). However, colonialism still prevails in the postcolonial state in the form of neocolonialism (Davie \& McLean, 2017). The effort of colonial powers to impose capitalist accounting systems to support extracting, accumulating and allocating economic surpluses hindered the development of accounting in these countries (Adhikari et al., 2013; Annisette \& Neu, 2004; Bakre, 2008). Wijewardana and Yapa (1998) show that in Ceylon, even after 50 years of independence, education is an inheritance stemming from the British colonial rule. This reality is the same, even today. In consequence, while, apparently sound accounting and accountability systems are in place, they play merely a 
ceremonial role to gain legitimacy mainly from the external funders rather than supporting controlling decisions (Alam, 1997; Hoque, 1995; Hoque \& Hopper, 1994, 1997; Uddin \& Hopper, 1999).

LDC governments at different times in history with the influence or assistance of international agencies attempted to introduce accounting reforms but failed due to their mismatch with the internal context merely becoming 'ceremonial' (Adhikari \& Jayasinghe, 2017; Hopper et at., 2017). For example, the World Bank, IMF and Asian Development Bank emphasised the dissemination of international accounting protocols as part of an enhanced accountability regime in these countries (Dissanayeke et al., 2019). Possible reasons for the failure of the reforms include inadequate institutional capacities and corruption (Mimba et al., 2007), the predominance of political interventions making accounting reforms irrelevant to rewards or actual circumstances (Helden \& Uddin 2016), and ignorance of rulers' political interests (Abeysinghe \& Samanthi 2016).

\subsection{Failure of Budgeting Practice}

In common practice, states use budgeting as a means of effective resource allocation towards poverty alleviation programmes (Goddard, 2010) to coordinate between its national development plans (Caiden \& Wildavsky, 1980; Wildavsky, 1964,1975). The state exerts control over public sector organisations through the government budget (Adam et al, 1992; Uddin \& Hopper, 2001; Wickramasinghe \& Hopper, 2005). Once approved by the legislature of the state, the government budget becomes the fundamental law for regulating spending during the fiscal year (Caiden \& Wildavsky, 1980). However, most LDC studies illuminate that the budgeting process of these countries has become a mere way of securing legitimacy from external authorities rather than supporting internal decisions (Alam, 1997; Alam \& Lawrence, 1994).

Budgets in these countries dysfunction and therefore create issues in the economic development (Hopper et al., 2017). According to Dean (1986) and Adhikari et al. (2013), although the Planning, Programming, Budgeting (PPB) practice introduced by the Sri Lankan Government in 1971 failed to serve the original purpose, continued to operate as the government budgeting system.

To Dean (1986), even the Auditor General did not use the budget data for investigations. Under this situation, by 2003, the Sri Lankan Government adopted Zero Based Budgeting (ZBB), which prevailed only up to 2006 (only for three years) due to a lack of understanding among local practitioners because a US consultant had introduced it. In Sri Lanka, PPB continues in practice despite its dysfunctional effects and, therefore, functions merely as a ritual. 


\subsection{The Theoretical Framework}

According to Burrell and Morgan (1979) and Hopper and Powell (1985), the ontological standpoint of the researcher drives the choice of methodology and, therefore, the choice of the theoretical framework. Thus, the realist ontology perceives that a budgeting system is an object having an existence independent to related human beings. In contrast, idealist, constructivist, or relativist ontology perceive that people subjectively perceive and construct the budgeting practice. This paper, with a relativist ontology, identifies ActorNetwork Theory (ANT) as the most useful to understand the outcomes of the investigation.

ANT helps us to know how we can organise and stabilise relationships to create a strong and robust network (Callon, 1992; Callon \& Latour, 1992; Callon \& Low, 1989), rejecting that 'social relations' are independent of the material and natural world (Latour, 2005). Instead, human beings form a social network, and interact with not only human beings but also other materials (Law, 1992). Thus, an actor-network is a heterogeneous network of actors with aligned interests such as people, organisations, and standards (Walsham \& Sahay, 1999).

Actors of a network include a focal actor, the one who initiates the network, other actors, who are taking part in and influenced by the network, and nonhuman actors such as budgeting system, administration and financial procedures, other regulations and technological instruments. "When an actor's strategy is successful, and it has organised other actors for its own benefit, it can be said to have translated them" (Sommerville, 1999, p. 9). The interest of the focal actor becomes the aligned interest of the network; "for scientific networks to be extended, actors must be interested, that is, their goals must somehow be aligned with those of the scientist" (focal actor) (Murdoch, 1997, p. 737).

The success of an actor-network depends on successful translation and continuity of the alignment of interests. If an actor defines itself differently from the others in the network, the translation does not occur, and the network fails (Hui, 2012). Aligned interest is an essential element for the success of a network among heterogeneous actors. The enrolment process involves "persuading other actors that they share a common interest or problem" (Doolin \& Lowe, 2002, p. 72). The successful actor-networks or alliances become 'black-boxed', where networks are stable and not questionable (Alcouffe et al., 2008).

Justesen and Mouritsen (2011, p. 164) classify ANT inspired accounting studies, focusing on methodological traditions. Some of them are ethnographic case studies (e.g., Preston et al., 1992; Briers \& Chua, 2001), while others are historical analyses, tracing the emergence of different accounting phenomena (e.g., Miller, 1991; Quattrone, 2004a, 2004b, 2009). Still, others draw on Latour's work to set forth new research agendas, methodologies and vocabularies that might inspire the community of accounting researchers (e.g., Lowe 2001, 2004a; 
Robson 1991, 1992), while a smaller number of papers engage in self-reflexive discussion about the relations between ANT and accounting studies (e.g., Chua 2004; Lowe, 2004b).

Accounting studies use ANT from several perspectives, understanding the process of the accounting change, understanding the diffusion of accounting innovation and understanding different accounting issues. Using ANT to study accounting change, Lowe (2001) illustrates how a heterogeneous network of actors, local and foreign, changes an accounting practice. Alcouffe et al. (2008), Arnaboldi and Azzone (2011), Becker at al. (2010), Boll (2014), Caron and Turcotte (2009) and Pipan and Czarniawska (2010) use ANT to explain how accounting changes have been achieved. Briers and Chua (2008), and Dissanayake et al. (2019) use ANT to discuss the process of diffusing accounting innovations. Whittle and Mueller (2010) explored the role of management accounting systems in the construction of the business strategy, and Komori (2014) explore tax compliance as to where it takes place and what it is made of. Using ANT, Lowe (2000) inquired into the role of accounting systems as a technology to influence decision-makers.

The current paper uses ANT as an analytical lens in investigating the formation of ritualist practice of the government budgeting system in Sri Lanka. From the ANT perspective, a budgeting practice is a non-human actor in a network where a government exerts its ruling as the focal actor. The rulers, as the focal actor, translate other actors. Aligned interest binds the constituents to the ruling network. The focal actor and the aligned interest of the colonial ruling in Ceylon changed with independence. However, the non-human actors such as budgeting and other control system continued with no change creating a tension between human and non-human actors of the network. Hence, this paper differs from other applications of ANT by illuminating the importance of 'aligned interest' in the continuity of a network, forming a particular accounting practice.

\section{Methodology}

The research design is a historical analysis starting from the emergence of the colonial ruling network, its aligned interest and human and non-human actors. The historical analysis benefits from ANT to explore how the budgeting process emerged and interacted with other actors of the ruling network in three time periods, the early colonial period from 1815 to 1931, the late colonial period from 1931 to 1948, and the postcolonial state from 1948 to 2019. This paper uses the budgeting practice of Sri Lanka Railways Department (SLRD), incepted in 1864 during the colonial rule, to illustrate the government budgeting practice. The study used archaeological sources for primary historical data, and, for secondary historical data, published materials. It used an examination of current records of SLRD and the Treasury, and data derived from interviews 
conducted with officials from the SLRD, Ministry of Transport and the Treasury to understand the current practice.

Table 1: Details of interviews

\begin{tabular}{|c|c|c|c|}
\hline Category of Data & Source of Data & Interviewee/s & $\begin{array}{c}\text { No. of } \\
\text { interviews }\end{array}$ \\
\hline \multirow[t]{4}{*}{$\begin{array}{l}\text { Practice of } \\
\text { budgeting from the } \\
\text { user perspective }\end{array}$} & $\begin{array}{l}\text { Experience of } \\
\text { the selected } \\
\text { SLRD officials }\end{array}$ & $\begin{array}{l}\text { Chief officer in charge of } \\
\text { overall operations of SLRD }\end{array}$ & 3 \\
\hline & & Two Senior Accountants & 5 \\
\hline & & An Administrative Officer & 1 \\
\hline & & $\begin{array}{l}\text { Two Senior Engineers } \\
\text { involved in the main } \\
\text { operations }\end{array}$ & 2 \\
\hline \multirow[t]{2}{*}{$\begin{array}{l}\text { State political } \\
\text { interferences }\end{array}$} & $\begin{array}{l}\text { Experience of } \\
\text { actors familiar } \\
\text { with SLRD } \\
\text { operations but } \\
\text { outside the } \\
\text { SLRD }\end{array}$ & $\begin{array}{l}\text { A retired General Manager } \\
\text { (Head of the Department) of } \\
\text { SLRD }\end{array}$ & 1 \\
\hline & & $\begin{array}{l}\text { A retired trade union leader } \\
\text { of the SLRD }\end{array}$ & 1 \\
\hline \multirow[t]{2}{*}{$\begin{array}{l}\text { Political concerns } \\
\text { related to SLRD }\end{array}$} & $\begin{array}{l}\text { Experience of } \\
\text { parliamentarian } \\
\mathrm{S}\end{array}$ & $\begin{array}{l}\text { A Retired Secretary to } \\
\text { COPA }\end{array}$ & 1 \\
\hline & $\begin{array}{l}\text { Experience of } \\
\text { ministerial } \\
\text { concerns }\end{array}$ & $\begin{array}{l}\text { A Senior Assistant Secretary } \\
\text { to the Ministry of Transport }\end{array}$ & 1 \\
\hline $\begin{array}{l}\text { Control over SLRD } \\
\text { from the Treasury's } \\
\text { perspective }\end{array}$ & $\begin{array}{l}\text { Experience of } \\
\text { The Treasury }\end{array}$ & $\begin{array}{l}\text { Officer in charge of financial } \\
\text { monitoring over SLRD from } \\
\text { the National Budget } \\
\text { Department of the Treasury }\end{array}$ & 1 \\
\hline
\end{tabular}

The study of the early colonial ruling network used data from Administration Reports and Sessional Papers before the State Council of Ceylon (1833-1931). Sessional Papers contain matters submitted to the Legislative Council for discussion, and this includes budget estimates and audit reports. Administration Reports contain the periodic operational progress which each Head of the Department submitted to the Governor. They contain financial as well as non-financial information on operational performance. For published materials, it used a few well recognised Sri Lankan historical studies, namely Jayawardena (1972, 2000), Munasinghe (2002), Silva (1981) and Weerawardena (1951). The study of the late colonial period obtained primary data from Administration Reports, Sessional Papers, and Hazards of State Council of Ceylon. The investigations of the postcolonial period obtained primary data from a content analysis of documentary sources and interviews. The content analysis used administration reports of the post-independent state, 
government's annual estimates (budgets) and minutes of the Parliamentary Committee on Public Accounts (COPA). Semi-structured interviews were used to gather relevant experience of personnel from the SLRD, the Ministry of Transport, the Treasury and the COPA of the Parliament, as shown in Table 1.

Each interview took a minimum of one hour. The researcher, being a former public servant working as an executive of the Treasury, had the privilege of accessing the Director of Operations and the Chief Accountant of SLRD, relevant personnel of the Treasury and the Ministry of Transport. The Director of Operations of the SLRD, with a positive attitude of researching the existing practice, facilitated the arrangement of rest of the links within SLRD. Secondary data for the post-independence investigations were obtained from an academic publication (Weerawardena, 1951), which describes the process of transferring the colonial administrative and financial systems to the post-independence Ceylon.

\section{Findings and Discussion}

This section presents data explaining developments that occurred in the ruling network in the early colonial ruling network (1815-1931), late colonial ruling network (1931-1948), and postcolonial ruling network (1948-2019).

\subsection{The Early Colonial Ruling Network in Ceylon (1815-1931)}

The British colonial rule occurred in Ceylon after negotiation with the then local rulers for several reasons. First, in 1796, they arrived as a result of a secret arrangement between the Kandyan king (native king of Upcountry region of Ceylon) and British officers, who were ruling 'South India', to help overcome the difficulties caused by Dutch rule (1656-1796) in the maritime stripe of Ceylon. Secondly, they had strong support from native leaders due to a dispute between the successor king and the aristocrats of his bureaucracy after the death of the Kandyan king in 1798. The sincere support from native leaders led the British rulers to take control of all Ceylon as a colony defeating the native king in 1815. Increasing opportunities for wealth accumulation for native leaders motivated this development, illustrating the formation of an actornetwork.

\subsubsection{Economic Interest as The Aligned Interest of the Network}

Economic interest drives the accumulation of wealth. Colonial rulers' economic interest is visible even in the intention of their initial conquest. To Silva (1981), the English East India Company had intentions of establishing a monopoly in cinnamon and pearl fishery in Ceylon, even before the Dutch surrendered their Maritime Province to it. When constituents of the network share the same interest, it is called aligned interest. 
From the ANT viewpoint, trade and administrative opportunities in the emerging colonial economy promoted the aligned interest of the network. By abolishing the trade restrictions imposed by the Kandyan monarch, the new British rule opened up new opportunities to residents in Kandy and the Maritime Provinces to venture into as traders. Besides, skilled artisans had the opportunity of undertaking construction contracts. Expanding import and export trade created opportunities for transport contracts with the government. Farming on the rent was another economic benefit to the natives. By the 1820s, the government started producing coconut oil using steam engines, providing opportunities for natives to supply necessary copra and firewood. Even in developing a railway service in 1864, the government were focused on the financial speculations and profitability of plantations rather than encouraging the indigenous sector (Munasinghe, 2002).

After three decades of British rule, the wealthy native families of the society had the opportunity to come out as planters of coffee and later extended to coconut, tea and rubber. The administrative opportunities created another category of actors called 'Mudaliyars', defined by Peebles (1973, p. 1), cited in Jayawardena (2000, p. 22), as "an economic and social status group 'mediating between the alien rulers and the bulk of the indigenous population' performing functions that the foreign rulers were unable or unwilling to do". Hence, the colonial administration became a source of capital accumulation, prestige and power for this native social group, who became another major category of actors to join the network.

By the 1850s, stimulated by economic and social growth, these bourgeois families started sending their children to England for education as a social passion. Some of these educated elites later became government officials serving the colonial administration while other political leaders, forming ideologies against the British rule. The latter group led the independence struggle until the British rulers granted independence in 1948.

\subsubsection{The Emergence of Budgeting Practice as A Non-Human Element}

In 1833, the Imperial Government in England granted semi-autonomy to the colonial government in Ceylon through a Legislative Council, which operated through a budget from the Imperial Government in England (Silva, 1981, Weerawardana 1951). Under this budget, the Imperial Government had total financial control except a small percentage for expenditure by the Governor.

In 1840, the non-official members of the Legislative Council demanded control over the budget, particularly for developing communication and irrigation (Weerawardana, 1951). In response, for the first time, the Governor's portion was transferred to the Legislative Council for control, marking the emergence of state budgeting in Sri Lanka. After that, more and more authority over the budget was transferred. For example, the Imperial Government 
granted the authority to pay for military and fixed establishment expenditure in 1848, and total defence expenditure in 1867. By 1912, the Legislative Council received full financial power, subject to the Governor's overriding authority. This budgeting continued until 1931.

\subsubsection{Controlling Role of The Budget as A Non-Human Actor}

The budget seems to have operated successfully exerting control in serving the economic interest during the colonial rule. A review of budget estimates for the periods 1885, 1886, 1912 and 1928 indicates that the budget format for the early colonial regime is identical. The investigations found three budgetary controls.

First, it makes specific provisions for items and amounts separately indicating rates of payments. This arrangement restricts the use of funds only for the intended purpose.

For example, the Ceylon Railway Service (SLRD) budget for 1885, provides specific rates of payments in a footnote for the 'workman expenditure' relating to railway workshops.

"Fitters at 16 cents to rupees 3.50; Blacksmiths 37 cents to rupee 1.50 per day;

Carpenters 25 cents to rupees 2; Masons 50 cents to rupees 2; Head carpenters rupees 2 to rupees 3; Head masons rupees 2 to rupees 3; Strikers 50 cents to 75 cents..." (Administration Report, 1885, p. 108).

Secondly, the administration report communicates performance on budgetary provisions. Each Head of the Department is to submit the Administration Report at the end of the budget period.

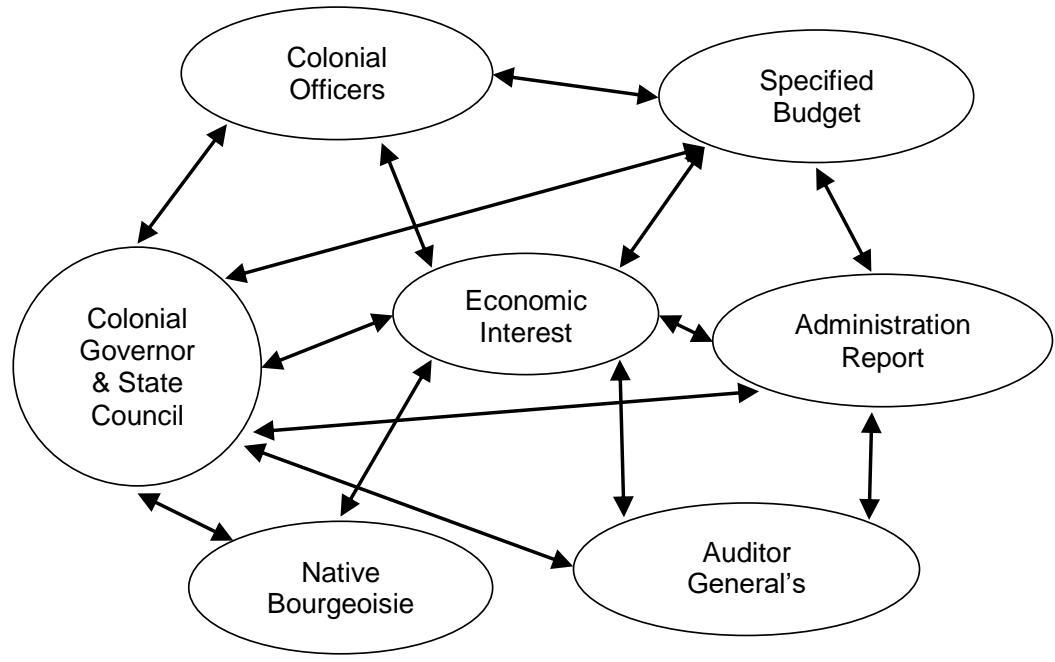

Figure 1: Early Colonial Actor-Network 1840 - 1931 
Thirdly, the 'Auditor General's Report' contained in the 'Sessional Papers' reports to the Legislative Council explanations on deviations in the budget achievements. For example, Financial Statements of the Department of Railway, reports its revenue amounted to Rs. 2,917,928 for 1885 against the budgeted Rs. 2,800,000. The Auditor General provides comments on the variance.

Thus, the Budget, Administration Report and Auditor General's Report are integrated to exert control over operations of the colony, making the budget an active non-human actor of the network. Figure 1 shows how human and nonhuman actors are integrated with the aligned interest of the early colonial ruling network.

In Figure 1, all human and non-human actors are linked with the economic interest and which is linked to the Colonial Governor \& State Council, the focal actor of the ruling network. The 'specified' budget, Administrative Report and Sessional Papers as non-human actors are again interlined.

\subsection{The Late Colonial Ruling Network (1931-1948)}

In response to the continued and worsening independence struggle demanding self-control, the Imperial Government in England introduced administrative reforms through the Donoughmore Commission in 1931 (Silva, 1981). The reforms replaced the Legislative Council with a State Council consisting of 58 members, of whom eight were held by the Governor, his three state officials and another four nominees.

The remaining 50 were native members elected through a formal election by the general public and were attached to seven Executive Councils, consisting of seven members and headed by a Chairman elected by them, responsible for assigned areas of public service. The Governor selected these chairmen as members of his Board of Ministers. The reforms assigned the operation of public services to native ministers, who were elected to the State Council by the general public including the non-bourgeoisie community.

It became the beginning of politics between politicians and the general public, particularly the non-bourgeoisie community, creating a political interest between the two groups. From the ANT perspective, the reform translated 'native rulers' and 'non-bourgeoisie community' and brought political interest into the network. The 'political interest' existed only between native leaders and non-bourgeoisie community. The 'economic interest' continued to be the aligned interest of the network. Budgeting and other non-human actors remained active with other actors of the ruling network. 'COPA inquiries' was introduced as a non-human actor. Figure 2 shows this change of the ruling network. 


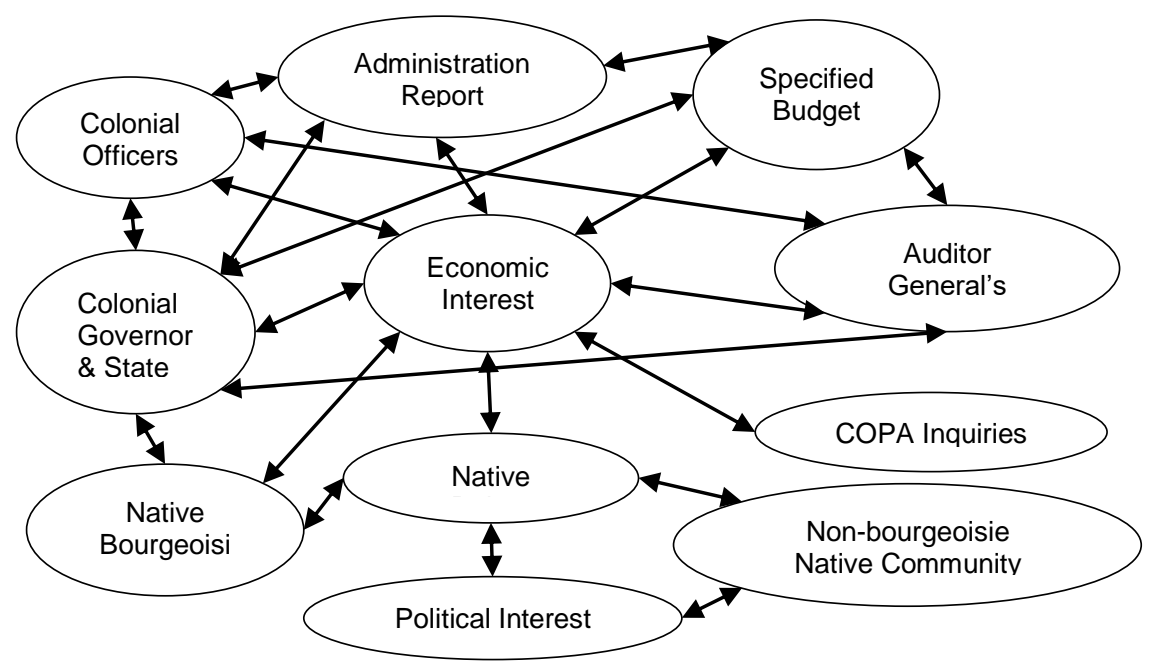

Figure 2: Late Colonial Ruling Network (1931-1948)

According to Figure 2, in the late colonial ruling network, all human and non-human actors related to the economic interest are interconnected, except the non-bourgeoisie community, which is isolated from the main ruling network, and connected only with the elected native rulers and their political interest.

\subsubsection{Change of Budgeting System in The Ruling Network - 1931}

The format of budget allocations changed, but provisions for 'specific items' remained unchanged. Provisions for expenditure in the budget were different from the past and classified into recurrent and capital items. Recurrent items included generic items as well as department-specific items. For example, estimates of the 'Development of Agricultural Marketing' for the year 1943/44 provides for recurrent expenditure under 22 items. Out of them, the first eight were generic items such as personal emoluments; travelling; stationery and office furniture etc. Under these generic items, the provisions were made in specific terms. For example, a provision comes under personnel emoluments, indicates details as; 15 Clerks from the General Clerical Service. It provides further details as to the number of employees under each grade of the service. These provisions also show the minimum and maximum limits of the expenditure. This avoids spending the budgetary provisions for different purposes. 
In preparing the budget estimates, a Treasury Circular informs Heads of Departments that they need to prepare their draft estimates and submit through the relevant minister with the recommendation by the Financial Secretary for the approval of the State Council (Weerawardana, 1951). For example, he opposed the proposal by the Ministry of Labour, Industry and Commerce for a Strychnine Factory in 1944 because it was not economically viable (Weerawardana, 1951, p. 51). The Governor had reserved the financial function to himself and therefore ministers, in spending on public services, were under the strict control of the Treasury. Although ministers had budgetary allocations, they did not have powers to spend without the concurrence of the Treasury. For example, the Minister of Labour, Industry and Commerce stated his concerns in the State Council in 1938;

"I have had a number of cases, which I can quote, where the Treasury thought that the Treasury alone was responsible for interpreting the way in which money voted by this House was to be spent, under a given sub-head" (Hanzard, 1938, p. 2551).

During the period, administration reports and audit reports continued to function in the same manner. Auditor General's report comment on the financial aspects of items in terms of revenue, expenditure and profit, reported in financial statements. In September 1945, for the first time, the Committee on Public Accounts (COPA) was introduced as another controlling tool to consider the Auditor General's report. However, the COPA inquiries were limited to matters relating to financial performance, especially the control over revenue and expenditure limits.

\subsection{Postcolonial Ruling Network - 1948}

In 1948, the British Imperial Government granted independence to Ceylon based on its 1947 Soulbury Constitutional reforms, transferring the rule from the colonial State Council to a Parliament of native representatives, ending the colonial rule and its economic interest. The changes occurred in the ruling network during this period include the change of aligned interest from economic to political, changes in human actors and dysfunctionality of nonhuman actors.

\subsubsection{Change in The Aligned Interest}

The colonial rule passed over masses and a working-class with a weaker economic base and having lots of welfare expectations caused by their long economic hardship (Jayawardena, 2000). This situation forced the native politicians, who were competing with different political ideologies, to be sensitive to the social welfare issue and to formulate policies to attract the majority of masses. This concern made the political interest the foremost priority of the postcolonial state. 
According to Jayawardena (2000), the immediate state of independent Sri Lanka had to start with a broader public sector, which made the behaviours of state officers critical for the government. Postcolonial rulers had the challenge from senior state officers with colonial mentality because the colonial rulers had recruited and trained them to serve the colonial needs. For example, a native scholar, who joined SLRD as a mechanical engineer in 1937, became its General Manager (Head of the Department) in 1956 and continued in the post till 1971. The attitudes of these senior officers and expectations created tension between them and the postcolonial rulers. A General Manager of SLRD who retired in the 1980s mentioned such an incident.

"Once early morning, when Mr Rampala (the GM mentioned before) was in the yard inspecting operations for the day, he got a message through his messenger that the Minister had come to see him and waiting at his office. You know what his response was that he had not given an appointment at this time and the minister had to wait until he finished the work and returned to the office."

This situation led the government in 1972 to take over the powers of controlling senior state officers to the hands of Cabinet of the Parliament. Before this, state officers' appointment, transfers and termination were handled by an independent Public Service Commission (Soulbury Constitution of Ceylon, 1947). The constitutional change occurred in 1978, and created a powerful executive presidency furthering the state officers' dependence on the Cabinet of Ministers. After this change, trade unions affiliated to the ruling political party became powerful such that they could influence senior state officers' decisions. The Cabinet of Ministers, exploiting the powers, appointed trade union leaders in positions of the administrative hierarchy. The retired GM recalled his memory about the appointment of a trade union leader, who was an Engine Driver of SLRD, as an 'Assistant Secretary' to the Ministry of Transport.

This situation led to increasing influences over managerial decisions at SLRD, compelling managers to disregard control systems for their personal safety. An Additional General Manager of SLRD explained.

"Managers tended to avoid their problems and started avoiding their involvements with railway problems. As a result, today nobody is bothered about managing expenditure. No one is concerned about improving services...We can't control anything because of trade unions...Management is now coping up with this situation...If we try to change these practices, they go on strike."

\subsubsection{Change in Human Actors in The Ruling Network}

After 1948, the Governor, colonial officials and their economic interest withdrew from the network, and the native rulers consisting of a Prime Minister and the Cabinet of Ministers of the Parliament became focal actors. Other ruling party members in the Parliament and the supportive bourgeoisie 
families remained connected. Senior state officers and the non-bourgeoisie community became active in the postcolonial ruling network.

\subsubsection{Dysfunctionality of Non-human Actors}

To Jayawardena $(1972,2000)$, the transfer of power to native rulers at independence was a result of a negotiation. Hence, in the 1930s, the colonial government started providing training to native educated elites for the civil service and professional services. As a result, by 1940, the Europeans and natives together operated the colonial administrative system. Under these conditions, no systems other than colonial accounting and administrative systems could continue to the postcolonial state. As a result, the colonial accounting, financial and administrative system met the postcolonial rule influenced by political interest. Despite the change of aligned interest to political, the colonial budgeting and accountability systems continued with no changes. For instance, Sessional Papers for 1959 presents the Auditor General's report with the same format, as appeared in 1947. The accountability inquiry system, COPA, formed in 1947, continued to the postcolonial state. During the State Council regime, the COPA was to inquire how far the native ministers had observed the budget limits enforced on public service expenditure (Weerawardana, 1951). Even today, the COPA performs the same function with its focus on controlling public service expenditure to prescribed limits. Thus, COPA inquiries did not support the needs of the prevailed political interest, and this caused the ruling politicians to neglect such control systems. A Director of SLRD explained this experience.

"Many of our expenditures do not comply with Financial Regulations. Several times those things were discussed at the COPA. But nothing has been rectified. Such meetings are limited merely to issue a report without taking any action. Department Heads, therefore, don't care about it."

A retired state officer, after long service as a Secretary to the COPA, corroborated this claim.

"There is no monitoring mechanism which operates as such. I don't think Treasury takes action on them. In my life, I think I have seen not more than two or three such instances. Practically, the COPA inquiry becomes the end of the matter. I think the COPA meeting is nothing but a tradition of legitimising different practices."

Over time, the postcolonial stated attempted some changes in budgeting. For instance, in the 1970s, the attempt to introduce programme budgeting ended with failure (Adhikari et al., 2013; Dean, 1986). Dean (1986) identifies insufficient support from legislature and executive, and the unsupportive accounting system as reasons for the failure. The former indicates the detachment of the budget from the political interest of rulers. The latter 
indicates the colonial legacy of the accounting practice. To Dean (1986), in the 1970s, commitment accounting practice was introduced replacing the cash basis of accounting, but it was beneficial to the Treasury's cash control rather than carrying out services by respective departments.

According to Adhikari et al. (2013) and Kurruppu (2010), the state attempted to bring the Zero-Based Budgeting approach as a public sector accounting reform during 2003-2006 but became unsuccessful. Investigations of the current study reveal that the Sri Lankan Government continues with programme budgeting with a constant financial focus. However, the postcolonial budget has deviated from the colonial practice leaving out the department-specific item-based provision of funds. Accordingly, the budget format common to any Ministry or Department presents the annual recurrent expenditure estimates for the year 2018 under five generic categories, personal emoluments, travelling expenses, supplies, maintenance expenditure, and services.

This standard classification creates a space for authorised persons, particularly to the Minister, to exercise discretion in accommodating personal preferences such as paying for casual employees appointed on the political patronage under personal emoluments. When the budget does not specify, the Administration Report does not complement the budget. The responses of many interviews with managers of SLRD and officers of the Treasury reveal that nobody is interested in the Administration Report. However, the audit report operates actively. The new actor-network is depicted in Figure 3.

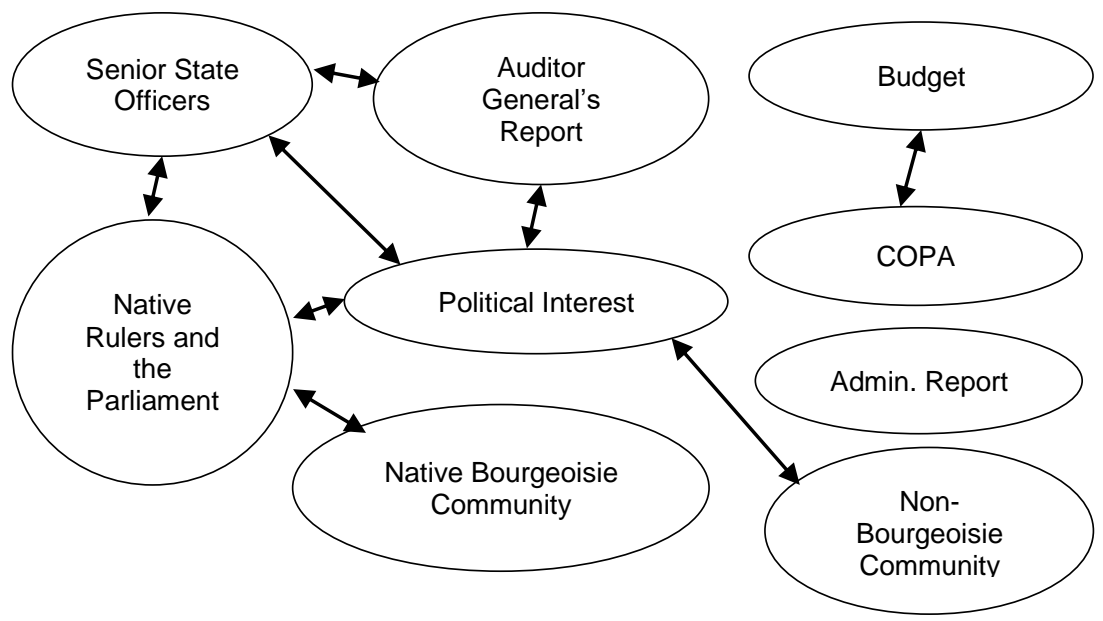

Figure 3: Postcolonial ruling network 
Figure 3 illuminates how the government budgeting system, administration report and COPA inquiries are detached from the aligned interest of the postcolonial ruling network and therefore become inactive. However, the native bourgeoisie community joined the colonial government for economic interest and is still connected to the rulers but not sharing the political interest. In the current context in Sri Lanka, this group provides financial support to rulers in their elections for economic benefits, violating the requirement of common interest among actors for a successful actor-network (Murdoch, 1997). Practically, this results in malpractices and corruption in the public sector as reported in many LDC studies such as Hopper et al. (2009), Hoque and Hopper (1994), Uddin and Hopper (2001), Wickramasinghe et al. (2004) and Wickramasinghe and Hopper (2005), COPA inquiries are connected with the budgeting as an accountability inquiry, but it also operates inactively as budgeting and administration report for the reason that it is detached from the political interest. Thus, the postcolonial ruling network seems to be a failed network where only a few actors share the aligned interest.

\section{Conclusion}

LDC accounting research draws attention mostly on accounting in the public sector and observes the ritualistic practice of sound accounting and control systems therein. Most of these countries are characterised by adverse politicoeconomic and cultural conditions and colonial histories, and have not been able to develop their accounting systems and practices. This has caused these countries to continue to operate colonial accounting systems amidst chronic issues of validity. The accounting reforms introduced to these countries have failed for the reason that they detach from their context.

Within this context, this paper sheds light on why the government budgeting in Sri Lanka operates as a ritual to achieve two objectives: (i) understanding how colonial legacies are manifested in the government budgeting practice and (ii) understanding why the selected government budgeting system operates as a ritual.

This paper closely investigated the budgeting practice of Sri Lanka Railway Department (SLRD) because government budgeting is same among government institutions such as Ministries and Departments, and therefore its findings apply to any government ministerial or departmental budgeting process. The investigations benefitted from ANT for the reason that ANT's ontological assumptions are supportive of an inquiry into the association between budgeting systems and human involvements therein because ANT is about how the interrelationships among actors of a network form reality. This study paid specific attention to the aligned interest of an actor-network, and its budgeting practice as a non-human actor. 
Accordingly, this paper, concurring with Doolin \& Lowe (2002), illuminates the importance of 'aligned interest' of a network in binding its human and nonhuman actors for its success. The investigations revealed the detachment of Sri Lanka Government budgeting, as a non-human actor of the ruling network from its aligned interest.

The formation of the colonial ruling in 1815 and its operation till 1931 demonstrate how the alignment of interest among human actors and complementary relationship among non-human actors of a network brings success to the actor-network outcomes. The colonial ruling began in 1815 as an actor-network based on economic interest as its aligned interest. In the first actor-network, the colonial Governor was the focal actor. Other actors included mainly colonial officers, local bourgeoisie, budget and other financial and administrative controls. The availability of economic opportunities to accumulate wealth aligned interest of the actors to the network. Budgeting practice as a non-human actor forming the plan and the practice of 'Administration Report' for its disclosure of operational performance, became complementary to ensure the achievement of intended outcomes. Auditor General's report confirmed financial results reported in the Administration Report and commented on variations in the budget and the actual performance reported in the administration report. Thus, the budget, administration report and Auditor General's report were strongly connected as non-human actors of the early colonial ruling network.

The actor-network from 1931 to 1948 shows how a network succeeds as far as aligned interest is maintained among human and non-human actors although multiple interests can occur among some human actors. In 1931, the Donoughmore constitutional reforms translated a set of local politicians elected by the general public through an election into the network. This group became ministers in the government having a political interest with especially the nonbourgeoisie majority of the native community. This constitutional reform was a response to the growing agitations mainly by the non-bourgeoisie community, led by some native bourgeoisie against the colonial rulers by way of an independent struggle. Hence, the colonial government had to allocate funds through the budget to operate public services through the native ministers. Accumulation of wealth continued as the aligned interest of the network despite the existence of political interest between native ministers and the non-bourgeoisie community. However, the colonial ruling network operated with the economic interest among the focal actor and other human and non-human actors. COPA inquiries were introduced in 1945 to inquire about the ministers' expenditure out of the budget. Accordingly, the budget, along with other non-human actors, controlled the use of funds for public services. 
The era from 1948 reveals how an actor-network becomes unsuccessful when the alignment of interest among human and non-human actors is lost. With the independence to the colony in 1948, the Colonial Governor, officers and the economic interest disappeared from the network. The native ministers became the focal actors and their political interest became the aligned interest of the postcolonial ruling network. The non-human actors such as the budget, Administration report and, Auditor General's report practices continued with no change to the new network for two reasons. First, the independence was granted based on a pre-preparation such as training senior officers and negotiation and second, the postcolonial state was not ready to develop its systems. Thus, the budgeting system used to serve colonial economic interest and the postcolonial political interest of the postcolonial ruling network.

The postcolonial budget underwent a change, replacing 'specific' categories with 'generic' categories of expenditure, creating a space for the discretion of ruling politicians. Nevertheless, this change did not align the budget with the political interest of the focal actors and therefore continued to deviate from the aligned interest of the network. When the budget became inactive, the need of the administration report was also lost. In consequence, both became redundant within the actor-network. The administration report continued to be prepared showing mainly financial outcomes, which is not relevant to the aligned interest of the network. The government in the early 1970s attempted to address this introducing programme budgeting (PPB). However, it failed by early 1980s after the change of the government in 1977. The government introduced Zero-Based Budgeting as an alternative action in 2003, but it failed by 2005 . Hence, the budgeting continues in the basic form of the PPB system.

Previous studies (Adhikari et al., 2013; Dean, 1986; Wijewardena \& Yapa, 1998) explained this failure, referring mainly to lack of knowledge and understanding of the practitioners, lack of support from the legislature and executive, lack of support from the accounting system, and lack of relevance to the local context. The current paper uses the ANT perspective to identify that it is mainly due to the budget's inability to serve the aligned interest of the ruling network.

In line with the State Council practice during the colonial rule, the budget operates as a statutory requirement and critical element in the ruling system allocating resources for the operations of the government. One may explain this as a practice of legitimation (Suchman, 1995).

Thus, the Sri Lankan Government budgeting practice carries colonial legacies in its financial focus, ignoring developmental outcomes required for the ruling politicians. It operates as a ritual because of its critical and statutory need and its mere habitual practice rather than purposive to serve the needs of the rulers and officers of the state. 
This paper contributes to the discussion of ANT illuminating and illustrating that aligned interest is key to the success of an actor-network, concurring with (Dooly \& Lowe, 2002; Hui, 2012; Murdoch, 1997). This paper also illuminates that accounting and control systems as non-human actors would be active only when they serve the broader aligned interest of the network. This finding concurs with Abeysinghe and Samanthi (2016), who conclude that the effort to bring accrual accounting would not be successful if the underlying political interests are not served. On the other hand, a network would be successful when all human and non-human actors of a network are involved in serving the aligned interest (Dooly \& Lowe, 2002; Hui, 2012). This finding also suggests that the continued failure of accounting reforms in LDCS as Adhikari et al. (2013) report, is caused by their ignorance of serving the political interest of the rulers and this paper derives a meaning to political interest in relation to a state as the interest to maintain relationships for mutual benefits. In a democratic state, it is the interest in achieving broader socio, economic and cultural development of constituents. Accordingly, deviations of human or non-human actors from the aligned interest of a ruling network hinder the development effort of LDCs.

Most importantly, this paper illuminates the validity of ANT as a theoretical framework to analyse and understand issues in a situation where different categories of people are involved for common interest. Failures or issues in adopting accrual accounting, public sector accounting standards and public sector reforms in the LDC context are frequently discussed. This paper suggests further research in those directions using ANT, which was found to be a useful theoretical framework for such studies.

Finally, this paper, draws the attention of policymakers of the LDC context, particularly in the Sri Lankan context, that to achieve development goals successfully, all the major human and non-human elements need to be aligned to the common interest. The current budgeting practice needs a crucial change to address the ruling needs deviating from the colonial model and to revamp other complementary control practices such as COPA inquiries, administration report and the Auditor General's report.

\section{References}

Abeysinghe, C., \& Samanthi, D. (2016). Accrual basis and political interest in public sector accounting: The case of a Municipal Council in Sri Lanka. International Journal of Academic Research in Accounting, Finance and Management Sciences, 6(3), 58-68. http://dx.doi.org/10.6007/IJARAFMS/v6-i3/2161

Adam, C., Cavendish, W., \& Mistry, P. S. (1992). Adjusting privatisation - case studies from LDCs. London: Ian Randle Publishers Ltd.

Administration Reports of Sri Lanka Railways Department from 1864 to 2004 
Adhikari, P., \& Jayasinghe,K. (2017). 'Agents-in-focus' and 'agents-in-context': The strong structuration analysis of central government accounting practices and reforms in Nepal. Accounting Forum, 41, 96-115. https:// doi.org/10.1016/j.accfor.2017.01.001

Adhikari, P., Kuruppu, C., \& Matilal, S. (2013). Dissemination and institutionalisation of public sector accounting reforms in less developed countries: A comparative study of the Nepalese and Sri Lankan central governments. Accounting Forum, 37, 213-230. https://doi.org/10.1016/j.accfor.2013.01.001

Alam, M. (1997). Budgetary Process in uncertain contexts: A study of state-owned enterprises in Bangladesh. Management Accounting Research, 8(2), 147-167. https:// doi.org/10.1006/mare.1996.0044

Alam, M., \& Lawrence, S. (1994). Institutional aspects of budgetary processes: A case study in a developing country. Asian Review of Accounting, 2(1), 45-62. https:// doi.org/10.1108/eb060645

Alama, M., Lawrence, S., \& Nandana, R. (2004). Accounting for economic development in the context of post-colonialism: The Fijian experience. Critical Perspectives on Accounting, 15, 135-157. https:// doi.org/10.1016/S1045-2354(03)00006-6

Alcouffe, S., Berland, N., \& Levant, Y. (2008). A virtual integration - The management control system in a multinational enterprise. Management Accounting Research, 19(1), 45-61. https:// doi.org/10.1016/j.mar.2007.08.001

Annisette, M., \& Neu, D. (2004). Accounting and empire: An introduction. Critical Perspectives on Accounting, 15(1), 1-4. https://doi.org/10.1016/S1045-2354(03)00002-9

Arnaboldi, M., \& Azzone, G. (2011). Trials of explicitness in the implementation of public management reform. Critical Perspectives on Accounting, 22(6), 550-566. https://doi.org/10.1016/i.cpa.2011.06.003

Auditor General's Report for the Ceylon Government Railways Department for 1885, 1912, $1935,1942,1955$ and 1966

Bakre, O. (2008). Financial reporting as technology that supports and sustains imperial expansion, maintenance and control in the colonial and postcolonial globalisation: The case of the Jamaican economy. Critical Perspectives on Accounting, 19(4), 487-522. https://doi.org/10.1016/j.cpa.2006.09.002

Becker, S. D., Jahala, T., \& Skaerbaek, P. (2010). Constructing performance measurement in the public sector. Critical Perspectives on Accounting, 21(4), 266-282. https:// doi.org/10.1016/j.cpa.2010.01.016

Bell, C. (1992). Ritual theory, Ritual Practice, NY: Oxford University Press.

Boll, K. (2014). The translation of accrual accounting and budgeting and the reconfiguration of public sector accountants' identities. Critical Perspectives on Accounting, 25(4-5), 324-338. https://doi.org/10.1016/j.cpa.2013.05.004

Briers, M., \& Chua, W. F. (2001). The role of actor-networks and boundary objects in management accounting change: A field study of an implementation of activity-based costing. Accounting, Organizations and Society, 26(3), 237-269. https://doi.org/10.1016/S0361-3682(00)00029-5

Briers, M., \& Chua, W. F. (2008). Actor-networks and the diffusion of management accounting innovations: A comparative study. Management Accounting Research, 19(1), 1-17. https://doi.org/10.1016/j.mar.2007.04.001

Burrell, G., \& Morgan, G. (1979). Sociological paradigms and organisational analysis. London: Heinemann

Caiden, N., \& Wildavsky, B. (1980). Planning and budgeting in poor countries, New Brunswick, Transaction Books 
Callon, M. (1992). The dynamics of techno-economic networks. In Coombs, R., Saviotti, P., \& Walsh, V. (Eds.), Technological change and company strategies: economic and sociological perspectives. (pp. 77-102). London: Harcout Brace Jovanovich.

Callon, M., \& Latour, B. (1992). Don't throw the baby out with the bath school! a reply to collins and yearley. In A. Pickering (Ed.), Science as practice and culture. (pp. 343-368), Chicago: University of Chicago Press

Callon, M., \& Law, J. (1989). On the Construction of Sociotechnical Networks: content and context revisited. Knowledge and Society: Studies in the Sociology of Science: Past and Present, 8, 57-83.

Caron, M., \& Turcotte, M. B. (2009). Path dependence and path creation: Framing the extrafinancial information market for a sustainable trajectory. Accounting, Auditing and Accountability Journal, 22(2), 272-297. https:// doi.org/10.1108/09513570910933979

Chua, W. F. (2004). Translating social theory: A critical commentary. Critical Perspectives on Accounting, 15(2), 255-60. https:// doi.org/10.1016/S1045-2354(03)00069-8

Davie, S. S. K. (2000). Accounting for Imperialism: A case of British-imposed indigenous collaboration. Accounting, Auditing and Accountability Journal, 13(3), 330-359. https:// doi.org/10.1108/09513570010334900

Davie, S. S., \& McLean, T. (2017). Accounting, Cultural Hybridisation and Colonial Globalization: A case of British civilising mission in Fiji. Accounting, Auditing and Accountability Journal, 30(4), 932-954. https://doi.org/10.1108/AAAJ-11-2013-1519

Dean, P. N. (1986). Performance Budgeting in Sri Lanka. Public Budgeting and Finance, Summer, pp. 63-75.

Dissanayake, T., Dellaportas, S. 1., \& Yapa, P. W. S. (2020). The diffusion-adoption of accrual accounting in sri lankan local governments. Financial Accountability and Management, 36(3), 261-277. https://doi.org/10.1111/faam.12222

Doolin, B., \& Lowe, A. (2002). To reveal is to critique: Actor-network theory and critical information systems research. Journal of Information Technology, 17(2), 69-78. https://doi.org/10.1080/02683960210145986

Frenkel. M., \& Shenhav, Y. (2006). From binarism back to hybridity: A postcolonial reading of management and organization studies. Organisation Studies, 27, 855-876. https:// doi.org/10.1177\%2F0170840606064086

Goddard, A. (2010). Contemporary Public Sector Accounting Research: An international comparison of journal papers. The British Accounting Review, 42(2), 75-87. https://doi.org/10.1016/j.bar.2010.02.006

Goodsell, C. T. (1989). Administration as ritual. Public Administration Review, 49(2), 161-166. https:// doi.org/10.1080/01900699708525227

Hanzard of the Parliament of Ceylon, 1938

Helden, J. V., \& Uddin, S. (2016). Public sector management accounting in emerging economies: A literature review. Critical Perspectives on Accounting, 41, 34-62. https://doi.org/10.1016/j.cpa.2016.01.001

Hemming, R., \& Mansoor, A. M. (1988). Privatisation and Public Enterprises: (IMF Occupational Paper No. 56). Washington, DC: IMF.

Hopper, T., \& Powell, A. (1985). Making sense of research into the organisational and social aspects of management accounting: A review of its underlying assumptions. Journal of Management Studies, 22(5), 429-465. https:// doi.org/10.1111/j.1467-6486.1985.tb00007.x

Hopper, T., Lassou, P., \& Soobaroyen, T. (2017). Globalisation, accounting and developing countries. Critical Perspectives on Accounting, 43, 125-148. https://doi.org/10.1016/j.cpa.2016.06.003 
Hopper, T., Tsamenyi, M., Uddin, S., \& Wickramasinghe, D. (2009). Management accounting in less developed countries: What is known and needs knowing. Accounting, Auditing and Accountability Journal, 22(3), 469-514. https:// doi.org/10.1108/09513570910945697

Hoque, Z. (1995). Budgetary control systems in public sector enterprises in a less developed country: Some evidence from Bangladesh. International Journal of Accounting, 3, 44-55.

Hoque, Z. \& Hopper, T. (1994). Rationality, accounting and politics: A case study of management control in a Bangladeshi jute mill. Management Accounting Research, 5(1), 530. https://doi.org/10.1006/mare.1994.1002

Hoque, Z., \& Hopper, T. (1997). Political and industrial relations turbulence, competition and budgeting in the nationalized jute mills of Bangladesh. Accounting and Business Research, 27(2), 125-43. https:// doi.org/10.1080/00014788.1997.9729539

Hui, D. (2012). Actor-Network Theory Analysis of The Budgetary Process in The New Zealand School Sector. Unpublished PhD thesis, Auckland University of Technology School of Business, NZ

Justesen, L., \& Mouritsen, J. (2011). Effects of actor-network theory in accounting research. Accounting, Auditing and Accountability Journal, 24(2) 161-193. https://doi.org/10.1108/09513571111100672

Jayawardena, V. K. (1972). The Rise of the Labour Movement in Ceylon, Durham, NC: Duke University.

Jayawardena, K. (2000). Nobodies to Somebodies. Delhi: Progress Printers.

Komori, N. (2014). Mapping tax compliance: assemblages distributed action and practices: A new way of doing tax research. Critical Perspectives on Accounting, 25(4-5), 293-303. https://doi.org/10.1016/j.cpa.2013.03.002

Latour, B. (2005). Reassembling the Social: An introduction to actor-network theory. Oxford: Oxford University Press.

Law, J. (1992). Notes on the theory of the actor network: Ordering, strategy and heterogeneity. Systemic Practice and Action Research, 5(4), 379-393. https://doi.org/10.1007/BF01059830

Lowe, A. (2000). The construction of a network at health Waikato: 'Towards clinical budgeting' project'. Accounting, Auditing and Accountability Journal, 13(1), 84-114. https:// doi.org/10.1108/02689230010359200

Lowe, A. (2001). After ANT: An illustrative discussion of the implications for qualitative accounting case research. Accounting, Auditing and Accountability Journal, 14(3), 327-51. https://doi.org/10.1108/EUM0000000005519

Lowe, A. (2004a). Post social relations: Toward a performative view of accounting knowledge. Accounting, Auditing and Accountability Journal, 17(4), 604-28. https://doi.org/10.1108/09513570410554579

Lowe, A. (2004b). Methodology choices and the construction of facts: Some implications from the sociology of scientific knowledge. Critical Perspectives on Accounting, 15(2), 207-31. https://doi.org/10.1016/S1045-2354(03)00067-4

Lukes, S. (1975). Political ritual and social integration. Sociology, 9, 289-308. https://doi.org/10.1177\%2F003803857500900205

McComas, K., Besley, J. C., \& Black, L. W. (2010). The rituals of public meetings. Public Administration Review, 70, 122-130. https://doi.org/10.1111/j.1540-6210.2009.02116.x

Miller, P. (1991). Accounting innovation beyond the enterprise: Problematizing investment decisions and programming economic growth in the UK in the 1960s. Accounting, Organizations and Society, 16(8), 733-62. https:// doi.org/10.1016/0361-3682(91)90022-7

Mimba, N. S. H., Van-Helden, G. J., \& Tillema, S. (2007). Public sector performance measurement in developing countries: A literature review and research agenda. Journal of Accounting and Crganizational Change, 3(3), 192-208. https:// doi.org/10.1108/18325910710820265 
Munasinghe, I. (2002). The colonial economy on track: Roads and railways in Sri Lanka (1800-1905), Colombo: The Social Scientists' Association.

Murdoch, J. (1997). The spaces of actor-network theory. Geoforum, 29(4), 357-374. https://doi.org/10.1016/S0016-7185(98)00011-6

Nkrumah, K. (1973). Towards Colonial Freedom, London: Panaf.

Peebles, P. (1973). The Transformation of a Colonial Elite: The Mudaliyars of nineteenth century Ceylon. PhD dissertation, University of Chicago.

Pfeffer, J. (1981). Power in organisations. Cambridge, UK: Ballinger Publishing Company

Pipan, T., \& Czzarniawska, B. (2010). How to Construct an Actor Network: Management accounting from idea to practice. Critical Perspectives on Accounting, 21(3), 243-251. https:// doi.org/10.1016/j.cpa.2008.04.001

Preston, A., Cooper, D. J., \& Coombs, R. W. (1992). Fabricating budgets: A study of the production of management budgeting in the National Health Service. Accounting, Organizations and Society, 17(6), 561-93. https://doi.org/10.1016/0361-3682(92)90014-J

Quattrone, P. (2004a). Accounting for god: Accounting and accountability practices in the society of Jesus (Italy, XVI-XVII centuries). Accounting, Organizations and Society, 29(7), 64783. https://doi.org/10.1016/j.aos.2004.03.001

Quattrone, P. (2004b). Commenting on a commentary? Making methodological choices in accounting. Critical Perspectives on Accounting, 15(2), 232-47. https://doi.org/10.1016/S1045-2354(03)00066-2

Quattrone, P. (2009). 'We have never been post-modern': On the search of management accounting theory. European Accounting Review, 18(3), 621-630. https://doi.org/10.1080/09638180902863837

Robson, K. (1991). On the arenas of accounting change: The process of translation. Accounting, Organizations and Society, 16(5-6), 547-570. https:// doi.org/10.1016/0361-3682(91)90041-C

Robson, K. (1992). Accounting numbers as "inscription": Action at a distance and the development of accounting. Accounting, Organizations and Society, 17(7), 685-708. https://doi.org/10.1016/0361-3682(92)90019-O

Sessional Papers of the Colonial Government of Ceylon for 1885, 1886,1912 and 1926

Silva, K. M. (1981). A History of Sri Lanka, Colombo: Vijitha Yapa Publications

Smith, A., \& Stewart, B. (2011). Organisational rituals: Features, functions and mechanisms. International Journal of Management Reviews, 12, 113-133. https://doi.org/10.1111/j.1468$\underline{2370.2010 .00288 . x}$

Somerville, I. (1999). Agency versus identity: Actor-network theory meets public relations. Corporate Communications, 4(1), 6-13.

Suchman, M. (1995). Managing legitimacy: Strategic and institutional approaches. Academy of Management Review, 20, 571-611. https://doi.org/10.2307/258788

Tsamenyi, M., Cullen, J., \& Gonzalez, J. S. G. (2006). Changes in accounting and financial information system in a Spanish electricity company: A new institutional theory analysis. Management Accounting Research, 17(4), 409-432. https://doi.org/10.1016/j.mar.2006.02.002

Uche, C. O., \& Atkins, J. F. (2015). Accounting for rituals and ritualization: The case of $\begin{array}{llll}\text { shareholders' } \quad \text { associations. } & \text { Accounting }\end{array}$ https://doi.org/10.1016/j.accfor.2014.10.006

Uddin, S., \& Hopper, T. (1999). Management Control, Ownership and Development: Experiences in privatised Bangladeshi enterprise", In Mackintosh, M. and Roy, R. (Eds). Macro-reforms and Micro-processes: Political Economy and Economic Management, London: Elgar. 
Uddin, S., \& Hopper, T. (2001). A Bangladesh soap opera: Privatisation, accounting, and regimes of control in a less developed country. Accounting, Organizations and Society, 26(78), 643-672. https:// doi.org/10.1016/S0361-3682(01)00019-8

Uddin, S., \& Tsamenyi, M. (2005). Public sector reforms and public interest. Accounting, Accountability and Auditing Journal, 18(5), 648-674. https:// doi.org/10.1108/09513570510620493

Walsham, G., \& Sahay, S. (1999). GIS for district-level administration in India: Problems and opportunities. MIS Quarterly, 23(1), 39-66.

Weerawardana, L.D.S. (1951). Government and Politics in Ceylon (1931-1946), Colombo: Ceylon Economic Research Association

Whittle, A. \& Mueller, F. (2010). Strategy, enrolment and accounting: The politics of strategic ideas. Accounting, Auditing and Accountability Journal, 23(5), 626-646. https://doi.org/10.1108/09513571011054918

Wickramasinghe, D., \& Hopper, T. (2005). A Cultural Political Economy of Management Accounting Controls: A case study of a textile mill in a traditional Sinhalese village. Critical Perspectives on Accounting, 16(4), 473-503. https://doi.org/10.1016/j.cpa.2003.07.001

Wildavsky, A. (1964). The Politics of the Budgetary Process. Boston: Little Brown.

Wildavsky, A. (1975), Budgeting: A Comparative theory of budgetary processes. Boston and Toronto: Little Brown.

Wijewardena, H., \& Yapa, S. (1998). Colonialism and accounting education in developing countries: The experiences of Singapore and Sri Lanka. The International Journal of Accounting, 33(2), 269-281. https://doi.org/10.1016/S0020-7063(98)90030-9 